\title{
Total patellectomy for patellar aneurysmal bone cyst
}

\author{
Patellar anevrizmal kemik kistinde total patellektomi
}

\author{
Mehmet Çetinkaya, MD., Hamza Özer, MD., Hakan Y. Selek, MD., Selim Erekul, MD. \\ Department of Orthopedics and Traumatology, Medical Faculty of Gazi University, Ankara, Turkey
}

\begin{abstract}
Herein we report a case of patellar aneurysmal bone cyst of a 32-year-old female patient who was admitted to our outpatient clinic due to the swelling on her left knee. She was describing no trauma history but increasing pain and that the mass was expanding gradually by the time. Although it occurs rarely in patella, evaluation by radiographic and magnetic resonance images revealed that the mass was due to the patellar aneurysmal bone cyst, which also destructed the surface of the joint. Although there was no impairment in the range of motion of the patient's left knee in the preoperative evaluation, because of the destruction, we performed total patellectomy and extensor mechanism reconstruction by Zaricznyj technique instead of curettage and grafting. The patient was satisfied with the procedure performed after the surgery and there was no complication in the follow-up.
\end{abstract}

Keywords: Aneurysmal bone cyst; patella; patellar ligament; patellofemoral joint.

Aneurysmal bone cyst $(\mathrm{ABC})$ is an expanding osteolytic and hyperplastic lesion with hyperemic and hemorrhagic character. For less than $1 \%$ of the primary bone tumors are aneurysmal bone cysts. ${ }^{[1,2]}$ Patellar occurrence of the tumor is rare and only $1 \%$ of all the $\mathrm{ABC}$ s are seen in the patellar bone. ${ }^{[1,3,4]}$ Many other tumors such as chondroblastoma, osteoblastoma, hemangioendothelioma, telangiectatic osteosarcoma and fibrous dysplasia have similar macro and microscopic findings. Aneurysmal bone cysts are mostly seen in female patients in their second decade of life. The reported cases in the literature have been treated with curettage and filling the cavity either with biologic material such as bone grafts, or with

\section{$\ddot{O} Z$}

$\mathrm{Bu}$ makalede, sol dizinde şişlik nedeniyle polikliniğimize başvuran 32 yaşında bir kadın hastada patellar anevrizmal kemik kisti olgusu sunuldu. Hasta öyküsünde herhangi bir travma tanımlamıyordu ve sol dizindeki mevcut şişlik ve ağrının giderek arttığını belirtti. Patellada çok nadir rastlanmakla birlikte, radyografik ve manyetik rezonans görüntüleme ile yapılan değerlendirmelerde, şişliğin patellanın eklem yüzeyini de harap eden bir anevrizmal kemik kistine bağlı olduğu görüldü. Hastanın cerrahi öncesi değerlendirmesinde diz eklemi hareket açıklığı normal sınırlarda olmasına rağmen, eklem yüzeyi harabiyetine bağlı olarak küretaj ve greftleme tedavisi yerine total patellektomi ve Zaricznyj tekniği ile ekstansör mekanizma rekonstrüksiyonu uygulandı. Hasta cerrahi sonrası dönemde yapılan işlemden memnun kaldı ve takiplerde herhangi bir komplikasyonla karşılaşılmadı.

Anahtar sözcükler: Anevrizmal kemik kisti; patella; patellar ligament; patellofemoral eklem.

synthetic material such as bone cement or with prosthetic implants..$^{[1,3-9]}$

\section{CASE REPORT}

A 32-year-old female patient with a history of slightly growing tumoral lesion on the left patella was admitted to our outpatient clinic. As far as she could remember there wasn't any significant trauma around the knee joint. In her physical examination a tumoral mass was clearly seen over the patella. The tumor was soft and slightly painful. She had a full range of motion without any restriction. No ligamentous instability was detected. A written informed consent was obtained from the patient.

- Received: April 06, 2015 Accepted: October 16, 2015

- Correspondence: Mehmet Cetinkaya, MD. Gazi Üniversitesi Tıp Fakültesi Ortopedi ve Travmatoloji Anabilim Dalı, 06500 Beşevler, Ankara, Turkey. Tel: +90 532 - $7969887 \quad$ Fax: +90 312 - 2129008 e-mail: gujcekic@gmail.com 
Lateral radiographs of the knee showed an osteolytic lesion affecting the whole patella. There was ballooning of the patella and partial loss of the bone at the patellar apex (Figure 1a). Sagittal magnetic resonance images showed fluid levels in the patellar cavity. Posterior articular cartilage was intact, and there was no sagittal image suggesting tumoral invasion or violation of the patellar borders (Figure 1b). Fat pad was pushed posteriorly by the expansile tumoral lesion and adjacent to the patellar inferior third articular cartilage. A technetium-99mMDP bone scintigraphy showed increased uptake in the left patella. These findings were compatible with aneurysmal bone cyst diagnosis; therefore excisional biopsy was planned for definitive treatment without preoperative incisional biopsy.

The patient was operated and marginal excision of the tumor with the whole patella was performed. After the knee was patellectomized the extensor mechanism was repaired via Zaricznyj technique. ${ }^{[10]}$ In the literature, there is no case report suggesting excision and Zaricznyj procedure for extensive patellar aneurysmal bone cyst.

On gross examination, bluish colored content of the cyst was clearly observed through the fenestrated part of the bone. Fat pad was adhered to the patellar inferior articular cartilage (Figure 2).

Histopathologic examination showed rich blood capillaries filled with multinucleated cells, osteoid tissue in calcified matrix, and histopathologic diagnosis was reported as aneurysmal bone cyst (Figure 3).
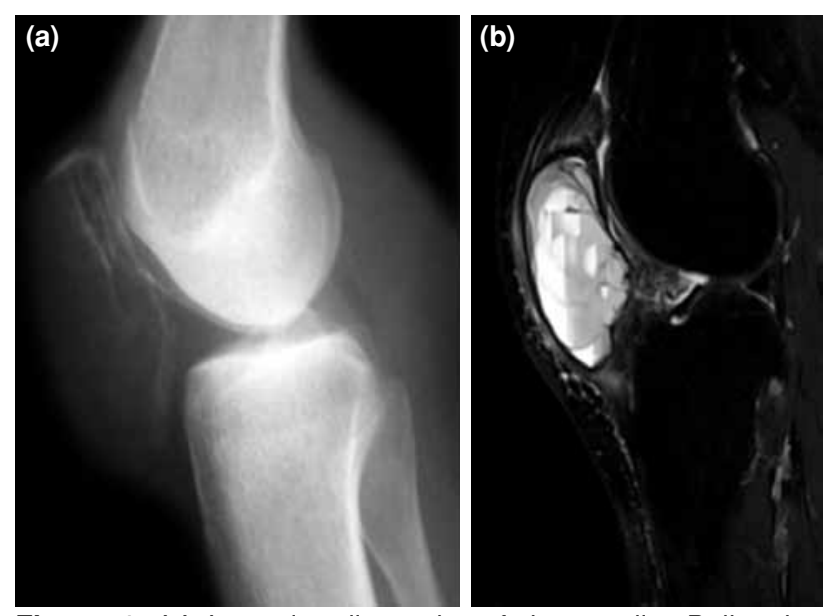

Figure 1. (a) Lateral radiography of the patella. Ballooning of the patella and partial loss of bone at the patellar apex. (b) $T_{2}$ weighted magnetic resonance imaging. Fluid levels in the patellar cavity and destruction of the articular surface at the inferior pole of the patella.
In the 22 months follow-up, the patient was pain free with full range of knee motion and had no complaints on the operated knee (Figure 4a-c). There was no sign of recurrence in the early follow-up.

\section{DISCUSSION}

Benign and malign tumoral conditions of the patella have been reported uncommonly in the literature. ${ }^{[2,7,11-13]}$ Aneurysmal bone cysts can be designated as primary or secondary due to histologic pattern. Intralesional treatment with curettage and void filling material either with auto/allogenic bone

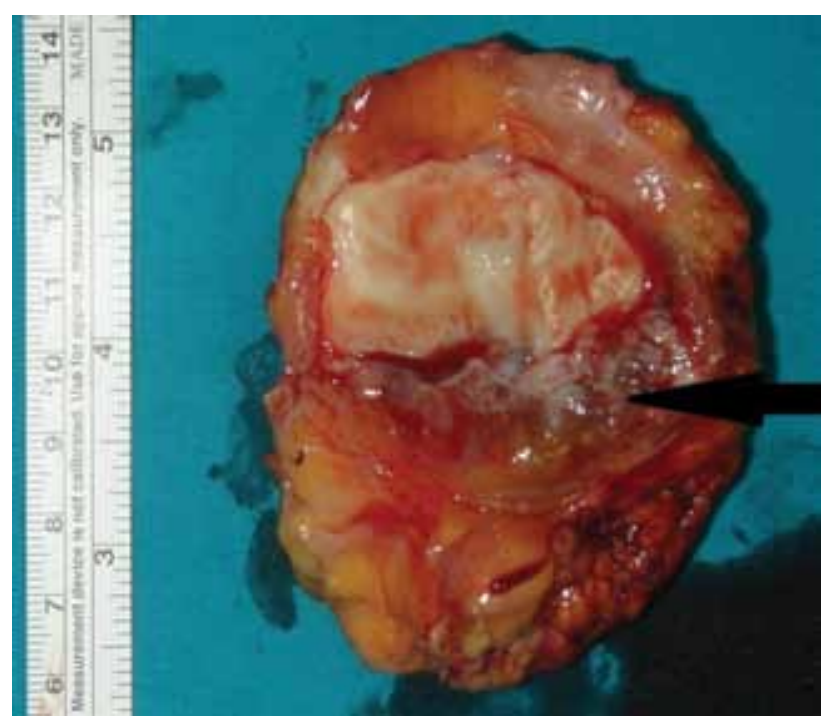

Figure 2. Total patellectomy material. Macroscopical examination reveals cortical erosion at the lower third of the excised patella.

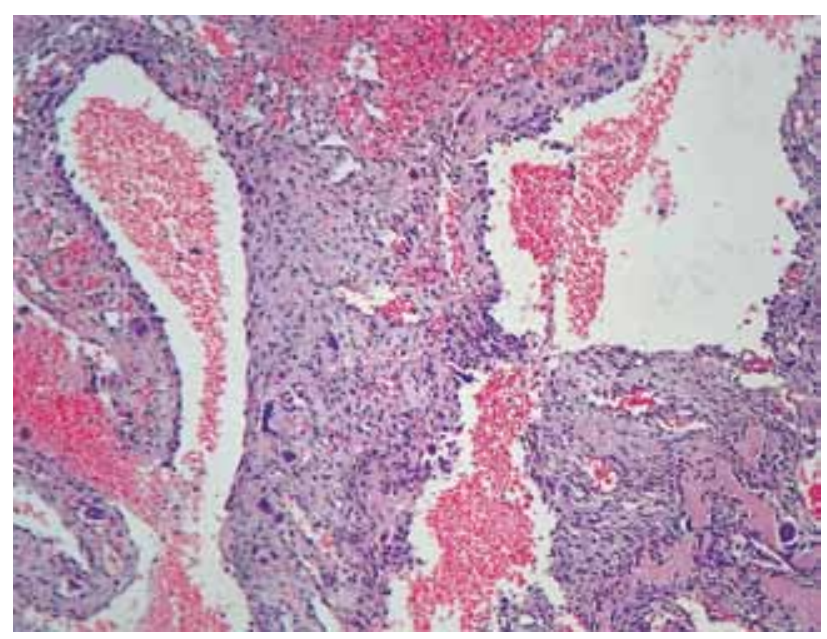

Figure 3. Histologic specimen stained with hematoxylin and eosin. Microscopic examination with magnification of 40x. Rich blood capillaries filled with multinucleated cells and osteoid tissue in calcified matrix. 

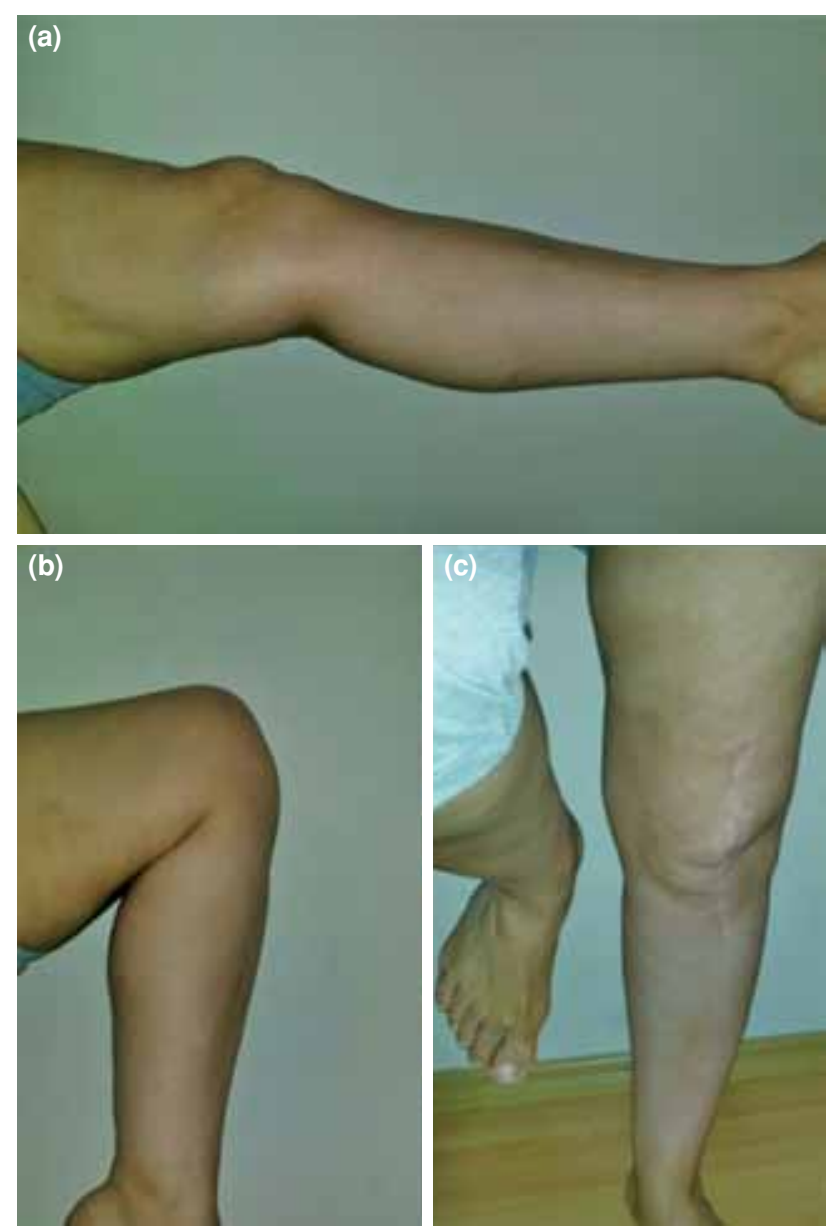

Figure 4. Active extension (a), active flexion (b) and the full-weight bearing (c) of the operated knee.

or synthetic material is recommended in stage 1 and II lesions where there is no destruction of the cortical structure of the patella. ${ }^{[3,4,8]}$ However, total excision of the patella is recommended in stage 3 lesions where the cortical structure has been destructed by the tumor. ${ }^{[1,3,4]}$ Recurrences of the tumor has been reported in the literature. Basarir et al. $^{[14]}$ reviewed 56 cases of $\mathrm{ABC}$ in pediatric population. They reported six recurrences in 56 cases that were comparable to the other reports in the literature. However, simple curettage with or without additional adjuvant therapy had been carried out in the initial treatment of the cases. Gibbs et al. ${ }^{[6]}$ presented a series of 40 patients with ABCs. They reported no recurrence in patients who had been treated with marginal excision of the tumor. In both studies the recurrence was noted in skeletally immature patients. Gibbs et al. ${ }^{[6]}$ stated that this could be related to the active biological process in the immature period of the patients.
In the presented case, though the tumoral lesion has expanded the patella and well preserved at the proximal half portion of the bone, apex of the patella has been destructed by expansion of the lytic lesion. The lesion had an eccentric location and multiple septas had been observed on the magnetic resonance images. Separate fluid levels were also detected in the osteolytic lesion. It was identified during the operation that the dorsal cortex of the patella beneath the extensor mechanism was disrupted. In order to decrease the chance of recurrence and decrease the risk of a patellar fracture, because of the thinned cortical bone, preserving the patella and curettage/grafting with or without adjuvant therapy was not preferred for this young patient. Therefore total excision of the patella and repair of the extensor mechanism was encouraged. In the literature, repair of the extensor mechanism with allograft material after marginal resection of the patella has been reported recently. However, disease transmission, for increasing the morbidity due to infection, should be remembered with allograft material in the follow-up period. ${ }^{[15]}$ Lavernia et al. ${ }^{[16]}$ reported acceptable results with patellectomized patients in his recently published study in the literature.

In her last follow-up, the patient had no symptoms of local recurrence and she was free of symptoms such as pain and for extensor impairment of the knee.

\section{Declaration of conflicting interests}

The authors declared no conflicts of interest with respect to the authorship and/or publication of this article.

\section{Funding}

The authors received no financial support for the research and/or authorship of this article.

\section{REFERENCES}

1. Campanacci M. Aneurysmal bone cyst. In: Campanacci M, editor. Bone and Soft Tissue Tumors. 2nd ed. New York: Springer Verlag; 1999. p. 812-840.

2. Shehadeh AM, Haiba MA, Henshaw RM, Lack E. Telangiectatic osteosarcoma of the patella. Orthopedics 2008;31:808.

3. Castro MD, Irwin RB. Aneurysmal bone cyst of the patella. Am J Orthop (Belle Mead NJ) 1996;25:717-9.

4. Görmeli G, Görmeli CA, Maraş Özdemir Z, Sevimli R, Akpolat N. [Article in Turkish] [A patellar giant-cell tumor with soft tissue involvement: an alternative treatment method and review of the literature]. Eklem Hastalik Cerrahisi 2015;26:110-5.

5. Dormans JP, Hanna BG, Johnston DR, Khurana JS. Surgical treatment and recurrence rate of aneurysmal bone cysts in children. Clin Orthop Relat Res 2004;421:205-11.

6. Gibbs CP Jr, Hefele MC, Peabody TD, Montag AG, Aithal $\mathrm{V}$, Simon MA. Aneurysmal bone cyst of the extremities. Factors related to local recurrence after curettage with a 
high-speed burr. J Bone Joint Surg Am 1999;81:1671-8.

7. Martinez V, Sissons HA. Aneurysmal bone cyst. A review of 123 cases including primary lesions and those secondary to other bone pathology. Cancer 1988;61:2291-304.

8. Oh JH, Kim HH, Gong HS, Lee SL, Kim JY, Kim WS. Primary aneurysmal bone cyst of the patella: a case report. J Orthop Surg (Hong Kong) 2007;15:234-7.

9. Seoh MS, Jeong HY, Jeong MY. Aneurysmal bone cyst in patella. A case report. J Korean Orthop Assoc 1983;18:799-803.

10. Zaricznyj B. Reconstruction of the quadriceps mechanism after patellectomy. J Bone Joint Surg [Am] 1972;54:1583-4.

11. Kumagai K, Abe K, Tomita M, Osaki M, Taura T, Tsurumoto $\mathrm{T}$, et al. Chondrosarcoma of the patella. J Orthop Sci 2008;13:556-60.

12. Malhotra R, Sharma L, Kumar V, Nataraj AR. Giant cell tumor of the patella and its management using a patella, patellar tendon, and tibial tubercle allograft. Knee Surg Sports Traumatol Arthrosc 2010;18:167-9.

13. Trebse R, Rotter A, Pisot V. Chondroblastoma of the patella associated with an aneurysmal bone cyst. Acta Orthop Belg 2001;67:290-6.

14. Başarir K, Pişkin A, Güçlü B, Yildiz Y, Sağlik Y. Aneurysmal bone cyst recurrence in children: a review of 56 patients. J Pediatr Orthop 2007;27:938-43.

15. Simonds RJ, Holmberg SD, Hurwitz RL, Coleman TR, Bottenfield S, Conley LJ, et al. Transmission of human immunodeficiency virus type 1 from a seronegative organ and tissue donor. N Engl J Med 1992;326:726-32.

16. Lavernia CJ, Alcerro JC, Drakeford MK, Tsao AK, Krackow KA, Hungerford DS. Resection arthroplasty for failed patellar components. Int Orthop 2009;33:1591-6. 